\title{
Therapeutic Properties of Honey
}

\author{
Frantzana Aikaterini ${ }^{1 *}$, Alexiou Dimitra' ${ }^{2}$, Panagiotopoulou Konstantina ${ }^{3}$, Ouzounakis Petros ${ }^{4}$ \\ and Tsiliggiri Maria ${ }^{5}$ \\ ${ }^{1}$ Department of Health Sciences, European University of Cyprus, Greece
}

${ }^{2}$ George Papanikolaou General Hospital of Thessaloniki, Greece

${ }^{3}$ Agia Sofia Children's Hospital, Greece

${ }^{4}$ Department of Physiotherapy of the International University of Greece, Greece

${ }^{5}$ Department of Physiotherapy of the International University of Greece, Greece

*Corresponding author: Aikaterini Frantzana, Department of Health Sciences, European University of Cyprus, Greece.

To Cite This Article: Frantzana Aikaterini. Therapeutic Properties of Honey. Am J Biomed Sci \& Res. 2019 - 4(6). AJBSR.MS.ID.000858. DOI: 10.34297/AJBSR.2019.04.000858

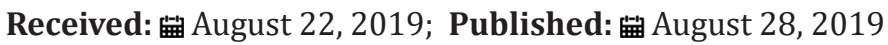

\begin{abstract}
Introduction: Honey is a product of high biological value and helps both the growth and strengthening of susceptible individuals. The history of honey begins in ancient times, where for many centuries, it was the only known sweetener. Even today, honey remains a key component of Mediterranean cuisine because of its high nutritional value.

Purpose: The purpose of this review is to inspect closely and thoroughly the usefulness of the nutritional value of honey and the healing properties of it.
\end{abstract}

Methodology: Regarding the methodology followed, a review was conducted through articles and books related to the subject using PubMed, Google Scholar and Scopus electronic databases with key words: honey, nutritional value of honey, therapeutic use of honey.

Results: The biological value of honey is determined by a series of beneficial effects that it causes to the human organism. Its antimicrobial action prevents the growth of bacteria and other pathogens. Its antiseptic properties help clean, disinfect or heal wounds and burns. Honey besides having a lower caloric value than sugar, it also has many other beneficial properties

Conclusions: In recent years, more and more people are turning to the consumption of natural products, including honey. The beneficial effect of honey on human health is widespread and its use as a food in our daily diet, as a product of superior caloric value, is increasing.

\section{Introduction}

Honey is a product of high biological value and helps both the growth and strengthening of susceptible individuals. In addition, nature gives us honey ready for consumption [1]. The history of honey begins in ancient times, where for many centuries, it was the only known sweetener. Homer in the Odyssey praises honey and its healing properties, while in the Iliad he refers to the preparation of an appetizer for Nestor, the king of Pylos, which consists of onions, bread, cheese and honey. Later, we come across texts written by Hippocrates, Dr. Galinos, Demokritos and Aristotle referring to the beneficial properties of honey for health and longevity [2].

Pythagoras and his followers used honey daily on their diet because they believed honey had antiseptic and medicinal properties. References are also made for the use of honey in the embalming of the dead. Honey continued to be widely used in Byzantium, while the bee was used as a symbol of Ephesus printed in coins at the time of its peak. Even today, honey remains a key component of Mediterranean cuisine because of its high nutritional value [3]. Beekeeping and honey production are one of the most important sectors of primary production, both in the European Union and in Greece. In Greece, beekeeping is quite widespread either as an exclusive or as a second job. It is a branch of rural economics, which contributes significantly to the income of both agricultural and urban families [4].

Honey is ripe and ready for consumption when it has a water content of $14-17 \%$. Immediately after ripening, honey is transferred into smaller containers to be available on the market for consumption or be stored. In Greece, the glass jar is preferred for the storage of honey because glass is a neutral material and does not react chemically with honey to alter its quality. Simultaneously, the consumer can distinguish the color, crystallization and purity of the honey $[5,6]$. Honey from antiquity to the 18 th century was the only confectionery for the man. The outlook that it has generally a beneficial effect on human health was and it is still widespread 
throughout the world. It is used as a tonic because of the glucose it contains, which is readily digested and metabolized by our body. It has a beneficial effect on our heart, liver and digestive system. Also, it has good antibacterial activity due to the presence of hydrogen peroxide (oxygenase) and high sugar concentration [7]. The purpose of this review is to inspect closely and thoroughly the usefulness of the nutritional value of honey and the healing properties of it. Regarding the methodology followed, a review was conducted through articles and books related to the subject using PubMed, Google Scholar and Scopus electronic databases with key words: honey, nutritional value of honey, therapeutic use of honey.

\section{Talking About Honey}

In accordance with Community law, honey is the natural sweetness, a sweet viscous food substance produced by Apis mellifera bees. They produce honey from the sugary secretions of plants - plant and floral nectar - or from excretions of other insects, such as honeydew or by regurgitation, enzymatic activity and water evaporation. Bees convert them into honey by mixing them with specific substances of their own body. Afterwards, they deposit, dehydrate, store honey in honeycombs, which are wax structures to mature (Table 1) [8].

\begin{tabular}{|c|c|}
\hline Qualitative criterion & Value Content \\
\hline \multicolumn{2}{|l|}{ Moisture } \\
\hline Calluna honey and honey for confectionery & $\leq 20 \%$ \\
\hline Calluna honey for confectionery & $\leq 23 \%$ \\
\hline Sum of fructose and glucose & $\leq 25 \%$ \\
\hline \multicolumn{2}{|l|}{ Nectar honey } \\
\hline Honeydew honey, a mixture of honeydew honey and flower honey & $\geq 60 \mathrm{~g} / 100 \mathrm{~g}$ \\
\hline Sucrose (sucrose) content & $\geq 45 \mathrm{~g} / 100 \mathrm{~g}$ \\
\hline \multicolumn{2}{|l|}{ Generally } \\
\hline $\begin{array}{l}\text { Robinia pseudoacacia, Medicago sativa, Banksia menziesii, Hedysarum, Eucalyptus camadulensis, Eucryphialucida, } \\
\text { Eucryphiamilliganii, Citrus fruits spp. }\end{array}$ & $\leq 5 \mathrm{~g} / 100 \mathrm{~g}$ \\
\hline Lavandula spp., Boragoofficinalis & $\leq 10 \mathrm{~g} / 100 \mathrm{~g}$ \\
\hline Non-water-soluble ingredients & $\leq 15 \mathrm{~g} / 100 \mathrm{~g}$ \\
\hline \multicolumn{2}{|l|}{ Generally } \\
\hline Honey (obtained by pressing the honeycombs) & $\leq 0,1 \mathrm{~g} / 100 \mathrm{~g}$ \\
\hline Electrical conductivity of honey & $\leq 0,5 \mathrm{~g} / 100 \mathrm{~g}$ \\
\hline \multicolumn{2}{|l|}{ Honey not mentioned as inferior honey and mixtures of this honey } \\
\hline $\begin{array}{c}\text { Honeydew honey and chestnut blossom honey and mixtures of this honey, other than mixtures with the listed below } \\
\text { honey }\end{array}$ & $\leq 0,8 \mathrm{mS} / \mathrm{cm}$ \\
\hline $\begin{array}{l}\text { Exceptions: Arbutus unedo, Erica, eucalyptus, lily (Tilia spp), callus callunavulgaris, Manuka or Jelly bush } \\
\text { (Leptospermum), tea plant (Melaleuca spp.) }\end{array}$ & $\geq 0,8 \mathrm{mS} / \mathrm{cm}$ \\
\hline \multicolumn{2}{|l|}{ Free acids } \\
\hline \multicolumn{2}{|l|}{ Generally } \\
\hline Honey for confectionery & $\leq 50 \mathrm{meq} / \mathrm{Kg}$ \\
\hline Schade scale & $\leq 80 \mathrm{meq} / \mathrm{Kg}$ \\
\hline \multicolumn{2}{|l|}{ In general, except for honey for confectionery } \\
\hline Honey with a low natural enzyme content (e.g. citrus honey) and whose HMF content does not exceed $15 \mathrm{mg} / \mathrm{kg}$ & $\geq 8$ \\
\hline HMF & $\geq 3$ \\
\hline \multicolumn{2}{|l|}{ In general, except for honey for confectionery } \\
\hline Honey of declared origin from tropical climate areas and mixtures of these honey & $\leq 40 \mathrm{mg} / \mathrm{Kg}$ \\
\hline
\end{tabular}

Honey is a complex natural product of world agricultural production derived from the bee. As a natural product, any honey, even if it comes from the same hive, may be different in terms of the ingredients contained or the quantities that are detected in the final product [9]. Plant and geographical origin and honey maturing conditions are the main factors responsible for the large number of honey ingredients and, consequently, for the physicochemical properties of the finished product. Thus, honey can contain several substances from 14 different types of ingredients: sugars, organic acids, water, proteins, amino acids, vitamins, minerals and trace elements, enzymes, flavonoids, furan derivatives, volatile aromatics, alkaloids, colloids $[10,11]$.

Produced honey can be divided into two major categories [12]:

a. Flower honey, produced from the nectar of the flowers, mainly thyme, orange, cotton, sunflower, heather, chestnut and

b. Honey from honeydew, produced by plant exudates or insect-ridden plants. This category includes honey from pine, fir and other forest plants. 
The study of honey components, in conjunction with information on its botanical and geographical origins but also other parameters, can explain the interactions that take place and shape its physicochemical characteristics. The physical properties of honey are a series of characteristic properties that honey acquires when it is mature, which can be modified during its storage [13,14]. Some of them are color, aroma and flavor, crystallization, fermentation, hygroscopicity, viscosity and density, its antimicrobial action, and so on. The physicochemical characteristics of honey are directly related to its organoleptic characteristics (flavor, color, aroma, fluidity) and the way the beekeeper or the consumer must manage honey after harvesting [15]. The composition and physicochemical characteristics of honey are among the most important parameters that help define the identity of a honey. The better we know the composition and the physicochemical properties of a honey, the easier it is to draw conclusions about its organoleptic characteristics, its microscopic characteristics and its exact origin, and put it in the right qualitative group.

Regarding the factors that may affect the color of honey, they are [9]:

a. The plant origin: The color of the honey depends on its plant origin; in other words, the plant and the part of the plant from which the bees were fed. As a rule, flower honey is lighter in color than honeydew honey which are dark-colored and black in some cases [16].

b. Moisture of honey: Honey harvested before sealing the cells well, before it matures, has a darker color than the typical color it would have after full maturation [17].

c. Crystallization of honey: Honey usually becomes lighter in color than normal due to the natural crystallization process [4].

d. Storage time and conditions: Stored honey becomes darker in color as a result of chemical changes in its ingredients. Changes in the color of the product are mainly affected by its content of fructose, colloids, copper, iron, its acidity and moisture content. The speed at which the color of the stored product is affected depends on the content of these chemical characteristics $[18,19]$.

e. Beekeeping: The beekeeper causes honey to become darker when [4]:

I. He places the honeycombs in the cells, which were used earlier in the honeybee nest.

II. He does not often renew honeycombs and he extract honey from old black honeycombs.

III. He extracts the honey from the honeybee nest.

IV. He does not use diaphragms for the queen.

f. Filtering: Good filtration immediately after harvesting helps to preserve the original color of honey [17].

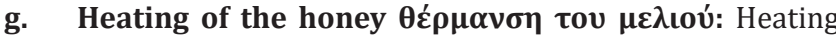
the product in any way affects, among other things, its color. The effect is insensitive to low temperatures and significant to high temperatures [3].

\section{Calorie Value}

Honey has an average of $304 \mathrm{kcal} / 100 \mathrm{~g}$. Its calorific value is directly related to its botanical origin (Table 2 ) and it is determined by various factors, such as the sugar content and their individual proportions, the moisture content, the presence of high molecular compounds etc. [7].

\begin{tabular}{|c|c|}
\hline Table 2: Calorie content of honey. \\
\hline Type of honey & Calories (Kcal / Kg) \\
\hline Pine 3.080 & Pine 3.080 \\
\hline Fir honey 3.422 & Fir honey 3.422 \\
\hline Thyme 3.515 & Thyme 3.515 \\
\hline Cotton 3,300 & Cotton 3,300 \\
\hline Orange 3,299 & Orange 3,299 \\
\hline Sunflower 3.755 & Sunflower 3.755 \\
\hline Heather 3.521 & Heather 3.521 \\
\hline
\end{tabular}

\section{Nutritional and Therapeutic Value of Honey}

The biological value of honey is determined by a series of beneficial effects that it causes to the human organism, actions that are due to its individual components [18]:

a. Honey sugars are more easily assimilated by the human body. Phosphates contained in honey help to make good use of glucose. Also, vitamins contained in honey, although at a low concentration, ensure the absorption and utilization of sugars [1].

b. It contains significant amounts of minerals and trace elements, essential for humans. The content varies greatly among the different types of honey. Indeed, at least for zinc, it has been proven that honey is found in the most readily assimilable form of the human organism and in quantities capable of greatly contributing to the satisfaction of daily needs of a man. In general, potassium, selenium and chromium $[20,21]$.

c. Honey contains calcium, iron, magnesium, phosphorus, vitamins B1, B2 and enzymes. These components of the honey give him irresistible medical properties [2].

d. Honey is tonic as it increases heart rate. Also, it reduces stomach ulcer problems, relieves insomnia, constipation, sore throats, and generally contributes to good functioning of the body [10].

e. Honey consumption helps in quicker recovery of health in cases of anemia due to the iron it contains. It is often used in cases of intoxication because it helps to accelerate the metabolism of alcohol by finally exempting the organism from this condition [1].

Its antimicrobial action prevents the growth of bacteria and other pathogens. Its antiseptic properties help clean, disinfect or heal wounds and burns [22]. In traditional medicine, it is used as 
a stimulant, tonic and antipruritic against anorexia and malaise, helps in cases of tiredness, coughing and colds, and finally makes sleep easy if consumed shortly before it.

The antibacterial action of honey is perhaps the only one of its biological properties, which is not questioned. The mechanism of its action in wound cleaning and healing or disinfecting of infected mucous membranes is somewhat easy to understand. Hydrogen peroxide $\left(\mathrm{H}_{2} \mathrm{O}_{2}\right)$ and gluconic acid contained in honey play a primary role for this purpose. Nectar has a neutral reaction [23]. As it matures and becomes honey, the bee adds the enzyme glucose oxidase, which converts it into gluconic acid, while hydrogen peroxide is formed as a byproduct. Honey thus acquires an acidic reaction to the extent that most bacteria cannot grow. $\mathrm{H}_{2} \mathrm{O}_{2}$ not only inhibits the growth of bacteria but also kills them [1,21]. A second milder antibacterial property is manifested by the high concentration of honey sugars, which causes the lymph to exit from a trauma. Bacteria are being drawn out together with the lymph, when exposed to gluconic acid and $\mathrm{H}_{2} \mathrm{O}_{2}$ action. The importance of $\mathrm{H}_{2} \mathrm{O}_{2}$ in honey is that it is continually being produced into honey and it is much more drastic the moment produced [19].

The bacteriostatic action of honey owed to glucose oxidation products is lost when the honey is warmed up. The only antibacterial effect is the one that can cause all solutions with a high sugar concentration (high osmosis) [10]. Finally, honey consumers should be aware that honey, if consumed in large quantities, is fattening. Honey contains an average of 3300 (range 3000-3800) calories per kilogram, while sugar 4000 calories. However, honey besides having a lower caloric value than sugar, it also has many other beneficial properties, as we mentioned earlier. In conclusion, eating up to 100 grams of honey every day has beneficial properties for the human body, without many calories $[20,21]$.

\section{Conclusions}

In recent years, more and more people are turning to the consumption of natural products, including honey. People tend to consume natural food again, both by their desire to seek a substitute for drugs in their various health conditions, and by trying to reduce the risks of frequent side effects of synthetic drugs.

The beneficial effect of honey on human health is widespread and its use as a food in our daily diet, as a product of superior caloric value, is increasing. It is a fact which is justified by the properties of honey.

\section{References}

1. L Kourkouta (1994) Honey, a Forgotten Medication. Proceedings of the $21^{\text {st }}$ Panhellenic Nursing Congress, Greece.
2. Kourkouta L, Rarra A, Fradelos E, Iliadis Ch (2013) Therapeutic Use of Honey from Greek Antiquity to Today. Balkan Military Medical Review 16(4): 456-461.

3. Thrasivoulou A Physical properties of honey.

4. Harizanis P (1996) Bee and beekeeping technique. $2^{\text {nd }}$ Edition, Greece.

5. Thrasivoulou A, Galanis K, Tanakaki X, Karazafiris E, Dimou M, Panagiotou P (2004) The quality of Greek honey. Proceedings of the $2^{\text {nd }}$ Scientific Conference of Beekeeping and Sericulture, Greece.

6. Alexakis AS (2003) Honey, Nature and Culture, Michalis Sideris. Athens.

7. Gounari S (2004) The beneficial effects of bee products on humans. Proceedings of the $2^{\text {nd }}$ Scientific Conference of Beekeeping and Sericulture, Greece.

8. Directive 2001/110/EC of the European Council.

9. Bikos T (1991) All About Honey. Psichalos Publications, Greece.

10. Alissandrakis E (2007) Differentiation of pure Greek honeys of orange, thyme and cotton based on their volatile compounds in honey. Doctoral Thesis, Agricultural University of Athens, Greece.

11. Tomás Berberán FA, Martos I, Ferreres F, Radovic BS, Anklam E (2001) HPLC flavonoid profiles as markers for the botanical origin of European unifloral honeys. Journal of Food and Agriculture 81: 485-496.

12. Balatsouras G (2006) Microbiology of Food. Embryo Publishing, Athens, Greece.

13. Thrasivoulou A, Manikis I (1995) Some physicochemical and microscopic characteristics of Greek unifloral honeys. Apidology 26(6): 441-445.

14. Anklam E (1998) A review of the analytical methods to determine the geographical and botanical origin of honey. Food Chemistry 63: 549-562.

15. Manikis I, Thrasyvoulou A (2001) The relationship of physiochemical properties of honey and the crystallization sensitive parameters. Apiacta XXXVI (3): 106-112.

16. Edgar JA, Roeder E, Molyneux RJ (2002) Honey from plants containing pyrrolizidine alkaloids: a potential threat to health. Journal of Agricultural and Food Chemistry 50(10): 2719-2730.

17. Arvanitogiannis IS, Varzakas Th (2007) Quality Food Control. Greece.

18. Xidias AT (1965) Good hives. $2^{\text {nd }}$ Edition, Royal National Foundation, Greece.

19. Kalkanis G, Hatiris I (2004) Organic Chemistry. Macedonian Publications, Greece.

20. Alyssandraki E This wonderful product.

21. Kouti M, Katimertzoglou I (2010) Mediterranean diet-The diet of the Ancient Greeks. Hellenes Publications, Greece.

22. White JW (1975a) Composition of honey. In: Honey, a comprehensive survey (by E. Crane) 5: 157-206.

23. Kourkouta L, Prodromidis K, Iakovidis D (2015) Alternative therapies in the treatment of bronchial asthma. Intraoperative Nursing 4(2): 58-65. 